\title{
Drifter Technique: a New Method to Obtain Metaphases in Hep-2 Cell Line Cultures
}

\author{
Eleonidas Moura Lima ${ }^{1,2}$, Jorge Dores Rissino ${ }^{3}$, Adriana Costa Guimarães ${ }^{1}$, David James \\ Overal $^{1}$, André Salim Khayat ${ }^{1}$, Patrícia Carvalho de Souza ${ }^{1}$, Denise Maria Christofolini ${ }^{4}$, \\ Marília de Arruda Cardoso Smith ${ }^{4}$ and Rommel Rodríguez Burbano ${ }^{1,4^{*}}$ \\ ${ }^{I}$ Laboratório de Citogenética Humana do Departamento de Biologia; Centro de Ciências Biológicas; Universidade \\ Federal do Pará; Curitiba - PR - Brasil. ${ }^{2}$ Departamento de Genética; Faculdade de Medicina de Ribeirão Preto; \\ Universidade de São Paulo; São Paulo - SP - Brasil. ${ }^{3}$ Departamento de Genética; Centro de Ciências Biológicas; \\ Universidade Federal do Pará; ${ }^{4}$ Disciplina de Genética; Departamento de Morfologia; Escola Paulista de \\ Medicina; Universidade Federal de São Paulo; Rua Botucatu 740; Edifício Leitão da Cunha; rommel@ufpa.br; \\ 04023-900; São Paulo - SP - Brasil
}

\begin{abstract}
The Hep-2 cell line is derived from laryngeal carcinoma cells and is often utilized as a model in carcinogenesis and mutagenesis tests. To evaluate the proliferative potential of this line, we developed a cytogenetic methodology (drifter technique) to obtain metaphases from cells that loose cellular adhesion when they underwent mitosis in culture. By this procedure, 2000 cells were counted, resulting in a mitotic index (MI) of 22.2\%. Although this MI was not statistically different from the one obtained using either a classical cytogenetic method or a cell synchronization technique, the drifter technique has the advantage of not requiring the use of some reagents for the obtention of metaphases and also of diminishing the consumption of maintenance reagents for this cell line.
\end{abstract}

Key words: Hep-2 cell line; drifter technique; mitotic index

\section{INTRODUCTION}

Cytogenetics experienced a great advance with the implementation of the technique for obtaining metaphases from peripheral blood (Moorhead et al., 1960). The technical difficulties for chromosome studies in solid tumors (necrotic areas, low mitotic index, poor quality of mitotic cells) and, most of all, the general and extensive variety and complexity of chromosomal changes represented obstacles to an accurate cytogenetic analysis (Burbano et al., 2000).
The Hep-2 cell line is derived from transformed laryngeal carcinoma cells (Birb and Forrester, 1981) and is frequently used in models for the study of carcinogenesis and mutagenesis (Grem and Fischer, 1989; Valdovinos and Gomez, 2003; Sinico et al., 2002). This line has a high proliferation rate, a 23-hours' cell cycle (Den Beste et al., 1966), and during mitosis a great number of cells loose cellular adhesion and remain suspended in the culture medium (Freshney, 1988). These characteristics make it possible to use them for cytogenetic preparations. In this

\footnotetext{
*Author for correspondence
} 
work, we used Hep-2 line cells suspended in culture medium to develop an alternative method for obtaining metaphase chromosomes (drifter technique). We compared the mitotic index (MI) obtained by this technique with two classical cytogenetic methods.

\section{MATERIAL AND METHODS}

Hep-2 line cells were cultured in $25 \mathrm{~cm}^{3}$ culture flasks at $37^{\circ} \mathrm{C}$ for 3 days. Their mitotic activity was observed daily in an invertoscope (AXIOVERT 25 - ZEISS) (Fig 1).

The cell line was maintained in vitro using Ham F10 culture medium complemented with fetal bovine serum $(10 \%)$.
Three different methods for mitosis acquisition were applied to compare the mitotic index. In all of them, colchicine was used for mitosis arrest. One method was the classical one, by which, after cell division was stopped by colchicine without cellular synchronization, the cells were removed from the culture flask by using trypsin-EDTA (Verna and Babu, 1995). A second method used cell synchronization (methotrexate/thymidine), colchicine and trypsin-EDTA (Yunis, 1981). The third one, the drifter technique, was carried out according to the following protocol: cells in suspension (during mitosis) were transferred to a $15 \mathrm{~mL}$ polypropylene test tube. To this $0.2 \mathrm{ml}$ of $10^{-5} \mathrm{M}$ colchicine was added and the suspension was kept at $37^{\circ} \mathrm{C}$ for one hour.

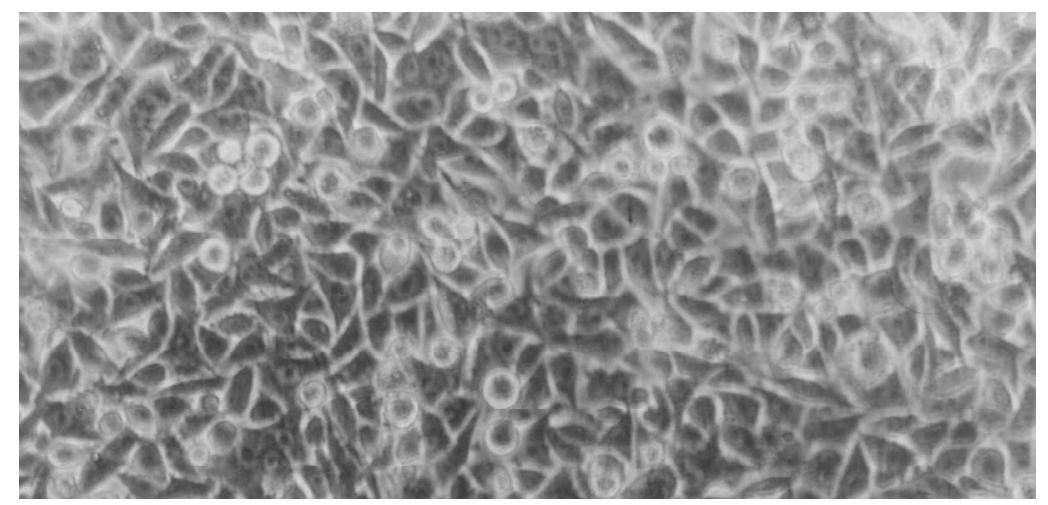

Figure 1 - Hep-2 line growth (16X) in monolayer with metaphase cells in suspension.

Then the suspension was centrifuged for eight minutes at $800 \mathrm{rpm}$. The sediment was resuspended in $5 \mathrm{ml}$ of hypotonic solution $(\mathrm{KCl}$ $0.076 \mathrm{M}$ ) and left to rest for 20 minutes at $37^{\circ} \mathrm{C}$. After centrifuging again, $7 \mathrm{ml}$ of Carnoy fixative 1:3 (glacial acetic acid:absolute methanol) were added. The cell preparation was washed in Carnoy fixative three times before preparing the slides, which were stained with conventional stain (Giemsa) for analysis. For each method 2000 cells were counted. MI calculation followed the formula: $\mathrm{M}=\mathrm{m} / \mathrm{N} \times 100$ (Rabello-Gay et al., 1991), where

$\mathrm{m}=$ number of cells in mitosis

$\mathrm{N}=$ number of cells in interphase plus number of cells in mitosis

$$
100=\text { percentage factor }
$$

The statistical analyses were carried out using Friedman's test or Fisher's exact test to compare the number of cells obtained by each technique (Ayres et al., 2000).

\section{RESULTS AND DISCUSSION}

There was no statistically significant difference between the mitotic index obtained with the three methodologies used in this study $(p>0.05)$. In the classical technique (trypsin-EDTA), 430 cells were found in mitosis, yielding a MI of $23 \%$. Cellular synchronization revealed 414 cells in mitosis and a MI of $20.7 \%$. The drifter technique showed 440 cells in cell division and a MI of $22.2 \%$ (Fig 2). These results are summarized in Table 1. The trypsin-EDTA methodology and the cellular synchronization technique are generally used to obtain metaphases from cell lines and solid tissue. In the first one, colchicine is added to the 
culture and the material is incubated for a few hours. Afterwards, the cells are removed from the surface of the flask by treatment with a trypsinEDTA solution (Verna and Babu, 1995), so that all cells in the culture are processed at the same time. However, by this method the cells do not enter mitosis simultaneously, and the number of metaphases may not be sufficient for analysis, requiring the maintenance of some samples for later processing. Using the drifter technique of cell suspension, those cells which do not enter mitosis remain attached to the surface of the flask and can continue their cell cycle, thus expanding the line.

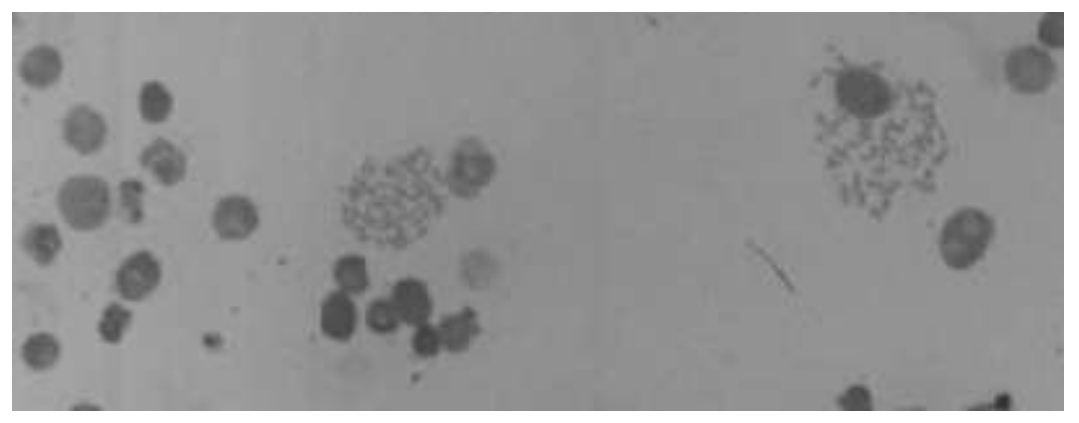

Figure 2 - Hep-2 line metaphase and interphase cells (16X) obtained using the drifter technique.

Table 1 - Mitotic indexes (MI) of the Hep-2 line using three different techniques for obtaining metaphases

\begin{tabular}{l|c|c}
\multicolumn{1}{c|}{$\begin{array}{c}\text { Technique for obtaining } \\
\text { metaphases }\end{array}$} & Number of cells in metaphase & Mitotic Index (MI) \\
\hline Trypsin-EDTA (classical) & 430 & $23.0 \%$ \\
Cellular synchronization & 414 & $20.7 \%$ \\
Drifter technique & 440 & $22.2 \%$ \\
\hline
\end{tabular}

By the cellular synchronization technique (Yunis, 1981), methotrexate (MTX) is added to the flask and left for 15 to 18 hours, after which the culture medium is changed for one with thymidine, and then the cells are re-incubated for 5 hours at $37^{\circ} \mathrm{C}$. Then colchicine is added and, after one to three hours of exposure, the cells are removed from the flask by treatment with trypsin-EDTA solution (Verna and Babu, 1995). The cell synchronization technique should increase the chances of obtaining metaphases when compared with the classical method (without synchronization), because MTX blocks the cell cycle of the cultured cells at the passage from G1 to $\mathrm{S}$ (Franks and Teich, 1997). However, the treatment with MXT is toxic for the cells and does not always produce an adequate number of metaphases; actually, this technique showed the lowest MI among the three methodologies. In addition, it should be kept in mind that this methodology also removes all the cells from the culture flask at the same time, and could require other samples, thus increasing the consumption of reagents for line maintenance. The use of the drifter technique reduces these costs, because the cells that have not entered mitosis will remain in culture, avoiding the need for trypsin, thymidine and MTX or any other cell synchronization drugs such as BrdU (Cheung et al., 1985) or FudR (Weber and Garson, 1983). The only disadvantage of the drifter technique is that it is ineffective on cells with low proliferation rate, where the other methods discussed in this study are preferable.

Thus, we suggest the use of the drifter technique for cell lines with a cellular biology similar to Hep-2, such as the human gastric adenocarcinoma cell line ACP01, the human colon adenocarcinoma cell lines HT29 and SW620, the human ovarian carcinoma cell line A2780, the human head and neck squamous cell carcinoma line UM-SCC-22B, 
the human breast carcinoma cell line MCF-7 and other cell lines that present a monolayer/multilayer growth pattern (substrate- dependent growth), because this method is both cost- and time-saving for obtaining metaphase chromosomes.

\section{ACKNOWLEDGEMENTS}

Research supported by FINEP CTINFRA/FADESP (No. 1017-01) and CAPES.

The authors are grateful to Ms. Glorita Santos for technical help.

\section{RESUMO}

A linhagem celular Hep-2 é formada por células de carcinoma da laringe e é muito utilizada em modelos de carcinogênese e mutagenêse. Para avaliar o potencial proliferativo desta linhagem, desenvolvemos uma metodologia citogenética (técnica do sobrenadante) para obtenção de metáfases a partir de células que, ao entrarem em mitose, perdem adesão celular, ficando em suspensão no meio de cultura. Através deste procedimento, foram contadas 2000 células, correspondendo a um índice mitótico (IM) de $22.2 \%$. Apesar de o IM obtido por esta técnica não ter sido estatisticamente diferente do IM obtido por outras metodologias citogenéticas clássicas, a técnica do sobrenadante é vantajosa porque elimina o uso de alguns reagentes utilizados na obtenção de metáfases e também diminui o consumo de reagentes de manutenção desta linhagem.

\section{REFERENCES}

Ayres, M.; Ayres Jr., M.; Ayres, D. L. and Santos, A. S. (2000), Bioestat 2.0: Aplicações estatísticas nas áreas de ciências biológicas e médicas. 2. ed. Brasília : CNPq.

Birb, B. R. and Forrester, F. T. (1981), Basic Laboratory Techniques in Cell Culture. Georgia : Health Service.

Burbano, R. R.; Medeiros, A; Amorim, M. I. M. Lima, E. M.; Mello, A.; Barbieri Neto, J. and Casartelli, C. (2000), Cytogenetic description of epithelial hyperplasias of the human breast. Cancer Genet Cytogenet, 119, 1-4.
Cheung, S. W.; Crane, J. P. and Burgess, A. C. (1985), High-resolution $\mathrm{R}$ banding in amniotic fluid cells using BrdU-Hoechst 33258 - Giemsa (RBG) technique. Hum Genet., 69, 86-87.

Den Beste, H. E; Fjelde, A; Jackson, J. L; Andresen, W. F; Kerr, H. A and Evans, V. J. (1966), Adaptation, growth, and chromosomal analysis of HEp-2 cells in chemically defined medium. J Natl Cancer Inst., 36, 1075-88.

Franks, L. M. and Teich, J. (1997), Cellular and Molecular Biology of Cancer. $3^{\text {rd }}$ ed. Oxford : Oxford University Press.

Freshney, R. I. (1988), Culture of animal cells. $2^{\text {nd }}$ ed. New York : Alan R. Liss, Inc.

Grem, J. L. and Fischer, P. H. (1989), Enhancement of 5-fluorouracil's anticancer activity by dipyridamole. Pharmacol Ther., 40, 349-71.

Moorhead, P. S.; Nowell, P. C.; Mellman, W. J; Battips, D. M. and Hungerford, D. A.(1960), Chromosome preparations of leukocytes cultured from human peripheral blood. Exp Cell Res., 20, 613-616.

Rabello-Gay, M. N; Rodrigues, M. A. R and Monteleone-Neto, R. (1991), Mutagênese, Teratogênese e Carcinogênese: métodos e critérios de avaliação. Revista Brasileira de Genética, Ribeirão Preto.

Sinico, R. A.; Bollini, B.; Sabadini, E.; Di Toma, L. and Radice, A. (2002), The use of laboratory tests in diagnosis and monitoring of systemic lupus erythematosus. J. Nephrol., 15 : (Suppl 6), S20-7.

Valdovinos, M. R. and Gomez, B. (2003), Establishment of respiratory syncytial virus persistence in cell lines: association with defective interfering particles. Intervirology, 46, 190-8.

Verna, R. S. and Babu, A. (1995), Human chromosomes: principles and techniques. $2^{\text {nd }}$ ed. New York : Mac Graw-Hill Inc.

Weber, L. M and Garson, O. M. (1983), Fluorodeoxyuridine synchronization of bone marrow cultures. Cancer Genet Cytogenet., 8, 123-132.

Yunis, J. J. (1981), New chromosome techniques in the study of human neoplasia. Human Pathol., 12, 540-549.
Received: August 22, 2003; Revised: April 23, 2004; Accepted: March 15, 2005. 